\title{
PSA Level 0.5 to 50
}

National Cancer Institute

\section{Source}

National Cancer Institute. PSA Level 0.5 to 50. NCI Thesaurus. Code C137707.

A blood concentration of prostate specific antigen between 0.5 and $50 \mathrm{ng} / \mathrm{mL}$. 